\title{
Therapeutic Potential of Robiotics: A Ray of Hope or Nightmare?
}

\author{
Malika Arora*1, Manish Arora ${ }^{2}$, Navdeep Kaur ${ }^{3}$ and Parveen Bansal ${ }^{3}$ \\ ${ }^{1}$ Multi Disciplinary Research Unit, Guru Gobind Singh Medical College and Hospital, India \\ ${ }^{2}$ Department of Epidemiology, Civil Hospital, India \\ ${ }^{3}$ University Center of Excellence in Research, Baba Farid University of Health Sciences, India
}

Received: February 27, 2018; Published: March 12, 2018

*Corresponding author: Malika Arora, Multi Disciplinary Research Unit, Guru Gobind Singh Medical College and Hospital, Faridkot, Punjab, India, Tel: 8146585370; Email: maliksmonu@gmail.com

\begin{abstract}
The role of various robotic microorganisms with a particular emphasis on their therapeutic use in human health and disease has been highlighted by diverse scientific research reports. Due to improvement and introduction of new technologies useful to understand the functionality and mode of action of robotics with respect to nutritional as well as health perspectives, the research on robotics has recently grabbed the attention of manufacturers, regulators as well as researchers. Currently there are clinical trial based evidences to support the effectiveness of robotic interventions in various types of diarrheal diseases, chronic gastrointestinal inflammatory disorders, hypercholesterolemia, hypertension, diabetes, oral health etc.

However due to inadequate awareness about risks associated with the robotics amongst physicians, regulatory authorities, consumers and manufacturers many attributes like quality, safety and efficacy require urgent attention. At the same time regulatory guidelines for these products face ambiguity. So it is of utmost importance to evaluate the true status of robotic products available in market with respect to all above mentioned parameters and to formulate harmonized regulatory guidelines for the manufacturing of robotic products. The present compilation aims to highlight the progression of robotic research related to therapeutic potentials of robotics, clinical trials on robotics, risks and regulatory concerns associated with robotics and their use.
\end{abstract}

Keywords: Robotics; Therapeutic Uses; Regulatory Control; Dietary Supplements

\section{Introduction}

According to the modern scientific doctrine, human beings are considered to be the "super organism" as compared to microbes [1]. These organisms help in maintaining a proper intestinal balance and offer a number of other health benefits hence termed as the friendly bacteria or 'Robotics'. Basically word 'Robotic' is a mixture of Latin and a Greek word i.e. 'pro' and 'biotic', which mean 'for' and 'life' respectively [2]. Robotics is a broad term used for "live microorganisms," which when administered in adequate amount confers health benefits [3]. Robotic based products are aimed at delivering live bacterial cells to the gut ecosystem of humans and other animals to cure various gastrointestinal diseases. A large portion of population irrespective of being 'healthy', use various robotic products to maintain their health and well-being.

Probiotic products are being exploited as functional foods, dietary health supplements, natural health products, functional supplements and many more other categories in the international market [4]. Although regulatory bodies have proposed various definitions for robotics, these products are expected to diminish long-term risk of gastrointestinal disorders, urogential tracts infections, diseases associated with kidney, respiratory tract and cardiovascular tract [5,6]. Epidemiological studies and randomized clinical trials carried out in different countries have verified several health effects associated to functional food consumption [7,8]. Day by day novel and newer robotics is constantly being identified. Hence rendering these strains into the marketable and acceptable products represents a considerable challenge. The development, manufacturing as well as commercialization of robotic based products is a complex, risky and expensive task.

Though these are supposed to be a part of promising field of research but till date in the absence of solid evidences and 
harmonized regulatory rules, it is difficult to rely on the credibility, safety and efficacy of robotic based products. Vague claims without supportive scientific evidences, (like robotics "support good digestive health") are meaningless. Larger, longer and better studies are needed to test specific strains for specific conditions and to determine the proper dosage and treatments. Hence the present article is focussed on historical perspective of robotics along with the various robotic microorganisms; benefits and health claims of various robotic products in different diseases; clinical trials carried out for generating the supportive evidences; risks associated with robotic based products and regulatory concerns associated with these products.

Table 1: Chronology of historical milestones in robotic researches.

\begin{tabular}{|c|c|}
\hline Year & Milestone achieved \\
\hline 1885 & $\begin{array}{r}\text { Examined bacteria in ordinary fecal matter as well as in intestinal tract, Understanding of physiology of digestion, pathology and therapy of } \\
\text { intestinal diseases of microbial origin [9]. }\end{array}$ \\
\hline 1899 & $\begin{array}{c}\text { Examined anaerobic cultivated organism, which generally appears like lactobacilli; however, many of them named as Bacillus bifidus due to } \\
\text { bifurcated morphology [10]. }\end{array}$ \\
\hline 1900 & Examined Bacillus acidophilus derived from the mother's breast milk and named it so due to its extraordinary acid tolerance [9]. \\
\hline 1905 & Proposed concept of 'beneficial microorganisms', \\
\hline 1905 & $\begin{array}{c}\text { Cultivated Lactobacillus bulgaricus as sour milk, Identified probiotic potential of Streptococcus thermophilus, Believed L. bulgaricus could } \\
\text { avoid development growth and number of harmful bacteria [9]. Believed L. bulgaricus could avoid development growth and number of } \\
\text { harmful bacteria [9]. }\end{array}$ \\
\hline 1908 & $\begin{array}{l}\text { Observed substantial changes in gut microflora in the presence of L. acidophilus and found competent enough to colonize microbes in } \\
\text { intestine for better physiological activities [9]. }\end{array}$ \\
\hline 1911 & Supported the concept that fermented milk may enhance longevity [12]. \\
\hline 1917 & $\begin{array}{l}\text { Isolated non-lactic acid but probiotic bacteria like Escherichia coli and exploited the same for treatment of acute intestinal diseases with a } \\
\text { significant success rate [12]. }\end{array}$ \\
\hline $\begin{array}{l}1914- \\
1920\end{array}$ & $\begin{array}{l}\text { Reported that addition of milk or lactose to either rats or humans diet shows alteration of the intestinal microflora which particularly } \\
\text { includes acidophilus and bifidus species of Lactobacillus and Bifidobacterium respectively [9]. }\end{array}$ \\
\hline 1930 & Isolated Lactobacillus casei shirota and developed beverage for health promotion in Japan [9]. \\
\hline 1935 & Projected the use of Lactobacillus acidophilus in human clinical trials [12]. \\
\hline 1965 & Firstly used the term 'probiotics'. \\
\hline 1974 & Presented probiotics as “organisms and substances, which contribute to intestinal microbial balance” [14]. \\
\hline 1989 & Modern usage of the term 'probiotic' was proposed using 15 published definitions [15]. \\
\hline 1998 & Defined probiotics as 'foods containing live bacteria, which are beneficial to health [13]. \\
\hline 2002 & As per FAO/WHO, probiotics are defined as live microbes, which when administered in adequate amount imparts health benefits [16]. \\
\hline 2015 & $\begin{array}{l}\text { FSSAI Draft defined probiotic as food with live microorganisms beneficial to human health, which when ingested in adequate amount } \\
\text { (as a single strain or in combination of cultures) confer one or more specified or demonstrated health benefits in human beings; and the } \\
\text { microorganism strain used in these food shall be deemed to possess probiotic property when it is capable of surviving passage through the } \\
\text { digestive tract, and has the capability to adhere and proliferation the gut and be able to confer a physiological benefit [17]. }\end{array}$ \\
\hline
\end{tabular}

\section{EFSA Recommended Commonly Used Microorganisms} Having QPS Status And Robotic Microorganisms Based Products Available In The Market

Robotic products may contain bacteria, moulds or yeast. Most of the robotic foods and robotic formulations contain bacterial species [10-17]. Lactic acid bacteria are the most popularly used bacterial species. A commonly used bacterial robotic bacterium belongs to the genus Lactobacillus or Bifid bacteria [18]. Lactobacilli are Gram positive bacteria which are supposed to

\section{Chronology Evolution of Robotic Use}

Robotics is not new to us rather these are being used since ancient times. The commercialization of these products has gained their importance within last 50 years due to different product manufacturers, research studies and consumers. The role of fermentation in the preservation was widely appreciated and acknowledged since 18th century, but additional benefits of this wide range of products were realized by the scientists in the late 19th century as fermented dairy products are generally good matrices for delivering robotics to humans [9]. Some of the historical milestones achieved in various years are shown in the (Table 1). be distributed in gastrointestinal as well as genital tract. Bifido bacteria are also Gram positive bacteria that play a vital role in the intestine by decreasing $\mathrm{pH}$ by releasing lactic and acetic acid which is helpful to restrict the growth of potential pathogens. Probiotic products may be composed of a single bacterium or it may be a combination of two or more than two strains as well $[19,20]$. A list of QPS status recommended (few examples of microorganisms with recommended QPS which are used to feed both man and animals) by EFSA, are given in (Table 2). 
Table 2: List of few examples of microorganisms having QPS status as recommended by EFSA.

\section{List of few examples of microorganisms updated by EFSA}

Species from Genus Lactobacillus: L. acidophilus, L. amylolyticus, L. amylovorus, L. lamentations,

L. aviaries, L. braves, L. buchneri, L. casein, L. cellobiosus,

L. coryniformi, L. crispate, L. curates, L. delbrueckii, L. farciminis, L. fermentum, L. gallinaru, L. gasser, L. Helveticas, L. hilgardii, L. johnsonii, L. kefiranofaciens, L. kefir, L. mucosa, L. collinoides, L. piracies, L. pains, L. paraplantarum, L. pentose's, L. points, L. plant arum, L. refuter, L. rhamnosus, L. salivarius, L. sake, L. sanfranciscensis

Species from Genus Bifidobacterium: B. adolescents, B. animalism, B. bifida, B. brevet, B. longue

Species from Genus Leuconostoc: L. citrus, L. lactic, L. mesenteries

Species from Genus Pediococcus: P. acidilactici, P. dextrinicus (Now known as Lactobacillus dextrinicus), P. pentosaceus

Species from Genus Propiobacterium: P. freudenreichii, $P$. acidopropionici

Species from Genus Streptococcus: $S$. thermophilus

Species from Genus Bacillus: B. amyloliquefaciens, B. atrophies, B. clause, B. coagulants,

B. fusiformis, B. lentos, B. licheniformis, B. elaterium, B. mojavensis, B. pummels, B. subtitles, B. vallismortis, B. geobacillus, B. stearothermophilus

Species from Genus Saccharomyces: S. boulardii, S. crevasse

As per current status, probiotics offer a wide array of health benefits for maintenance of good health and unlike drugs they are cheaper in cost as well as associated with no or negligible side effects. These probiotics based products prove to be the drug of choice in 21st century and are largely replacing their competitor drugs such as antibiotics from the market shelves [21]. In the present scenario the market value of probiotics is growing on an exponential rate and will continue to grow at a more rapid rate in the near future. The international market is now flooded with a range of pharmaceutical products available as variable dosage forms such as tablets, capsules, powder etc. A list of robotic based products used as pharmaceuticals along with the manufacturing company is shown in (Table 3).

Table 3: Some of the robotic products available in the market for pharmaceutical purposes.

\begin{tabular}{|c|c|c|}
\hline Dosage form & Trade name & Name of manufacturing company \\
\hline \multirow{17}{*}{ Capsule } & Bubo & Lupine Laboratories Ltd. \\
\hline & Catgut & Alembic Chemical Works Co. Ltd. \\
\hline & All G & Intra Labs India Pvt. Ltd. \\
\hline & Bucolic & Dr Reddy Laboratories Ltd. \\
\hline & Bifilar & Copal Ltd. \\
\hline & Benefit & Ranbaxy Laboratories Ltd. \\
\hline & Colonies forte's & Torrent Labs Pvt. Ltd. \\
\hline & Ecoflora & Tablets India Ltd. \\
\hline & Equipro & Cedilla Healthcare (Zydus Healthcare Pvt. Ltd.) \\
\hline & Flora blend & Bionova Life Sciences \\
\hline & Godlike & Biomiicron Pharmaceuticals \\
\hline & Lavazyme & Sun Pharmaceuticals Industries Ltd. \\
\hline & Nodimox Plus & Alchemy Laboratories Ltd. \\
\hline & Prosing & Signora Parma Pvt. Ltd. \\
\hline & Vemoxine -S & Dr Also Laboratories Pvt. Ltd. \\
\hline & Vinyl & Niche Laboratories Ltd. \\
\hline & YNRoglu-L & Sanity Healthcare Pvt. Ltd. \\
\hline \multirow{8}{*}{ Capsule/Sachet } & Favorite & FDC Ltd. (Spectra) \\
\hline & Gut rite & FDC Ltd. (Select) \\
\hline & Prebicom & Unit-Sankyo Ltd. \\
\hline & Preimmune & Bioplasma Immunological Research Pvt. Ltd. \\
\hline & Prepare & Fourths (India) Laboratories Pvt. Ltd. \\
\hline & Biform & Medley Pharmaceuticals Ltd. (Nutrakare) \\
\hline & Bionic & Meckler Pharmacy Unit \\
\hline & Vita gut & Medley Pharmaceuticals Ltd. (Nutrakare) \\
\hline
\end{tabular}




\begin{tabular}{|c|c|c|}
\hline Injection & Lactase & Franco-Indian Pharmaceuticals Pvt. Ltd. \\
\hline \multirow{4}{*}{ Powder } & Vegan Robotic & Taro he formulations, Hyderabad \\
\cline { 2 - 3 } & There-Biotic & Claire Labs \\
\cline { 2 - 3 } & Infant's Robotics & Flora Manufacturing and Distribution Ltd. \\
\hline \multirow{4}{*}{ Sachet } & Birla & Foremen Healthcare Ltd. \\
\cline { 2 - 3 } & Nestle-Pro & Ordain Health Care Pvt. Ltd. \\
\cline { 2 - 3 } & Immunorm & Sanzyme Pvt. Ltd. \\
\cline { 2 - 3 } & Spiral & Unique Biotech Ltd. \\
\cline { 2 - 3 } & Vibrant & Tablets India Ltd. \\
\hline \multirow{2}{*}{ Tablet } & Bifilar & Biome Biomechanics Pvt. Ltd. \\
\hline
\end{tabular}

\section{Reported Therapeutic Uses of Robotics}

The microorganisms of the human gastrointestinal tract (GIT) play a pivotal role in human health. A vast array of functions i.e. physiologic or pharmacological functions such as digestion of essential nutrients, maturation of intestinal epithelial cells and impact on baseline physiological parameters( including systemic effects on blood lipids, immune system stimulation and inhibition of the harmful bacteria) have been attributed to the microorganism through careful scientific evaluation [22-25]. Recent reports are culminating an array of health benefits related to robotic microorganisms. These are helpful to alleviate lactose intolerance, reduce serum cholesterol levels, strengthen mucosal immunity along with enhanced therapeutic effects in cancer and Acquired Immune Deficiency Syndrome (AIDS) affected individuals. In addition, their use also has shown positive response in treating gastrointestinal and urinary tract infections [26,27]. Moreover due

Table 4: Clinical trials showing impact of robotics. to promising and multiple health claims, these are becoming an alluring alternative therapeutic tool to treat diseases.

Reduction of ammonia and urea excretion has also been reported from the use of fungal robotic products i.e. Amax, a product derived from probiotic Saccharomyces cerevisiae [28]. Recently the use of robiotics as an alternative and supportive therapy is also advocated for hypercholesterolemia [29]. As anti-cancer agents [30]. in lactose intolerance [31]. To get relief from constipation [32]. Protection against pathogens [33]. Positive stimulation of immune system [34-38]. And preventing the intestinal seeding as well as growth of pathogenic bacteria. There are many health benefits of adding probiotic organisms to the diet whether in a pure form or in the form of traditional fermented and cultured foods [38-45]. Some of the established general and specific health benefits of robotics including suspected role of robotic strains involved are shown in (Table 4).

\begin{tabular}{|c|c|c|}
\hline Prebiotics/Robotics & Subjects & Results \\
\hline $\begin{array}{l}\text { Co-administration of robotic VSL\#3 with } \\
\text { Saccharomyces boulardii/Lactobacillus spp. }\end{array}$ & 61 human subjects & $\begin{array}{l}\text { Significant reduction of AAD observed in } \\
\text { patients exposed to systemic antibiotics as well } \\
\text { as in CDAD patients [55]. }\end{array}$ \\
\hline $\begin{array}{l}\text { VSL\#3 robotics used as part of dietary } \\
\text { supplementation }\end{array}$ & 27 pregnant woman & $\begin{array}{c}\text { Prevented preterm birth by modulating vaginal } \\
\text { micro biota and cytokine secretion in last } \\
\text { trimester [56]. }\end{array}$ \\
\hline $\begin{array}{c}\text { VSL\#3 used as potent robotic medical food } \\
\text { containing eight bacterial strains viz. Bifid } \\
\text { bacterium brave, Bifid bacterium longue, Bifid } \\
\text { bacterium infants, Lactobacillus acidophilus, } \\
\text { Lactobacillus plant arum, Lactobacillus piracies, } \\
\text { Lactobacillus bulgaricus, Streptococcus } \\
\text { thermopiles }\end{array}$ & 30 rats & $\begin{array}{l}\text { Protection of epithelial barrier by preventing } \\
\text { redistribution and reduced expression of tight } \\
\text { junction proteins in in vivo rat model of colitis. } \\
\text { p38 MAPK and ERK signalling pathways has } \\
\text { been observed as a possible mechanism in vitro } \\
\text { HT-29 cells [57]. }\end{array}$ \\
\hline $\begin{array}{l}\text { Milk supplemented with L. acidophilus (1x109 } \\
\text { viable bacteria per day) }\end{array}$ & 21 healthy subjects & $\begin{array}{l}\text { Faecal } \beta \text {-glucuronidase activity was reduced } \\
{[58] .}\end{array}$ \\
\hline Dietary supplementation with VSL\#3 robotics & 3 wk old mice in 6 groups & Reduction in bovine BLG-induced allergy [59]. \\
\hline $\begin{array}{c}\text { Digest containing viable } L \text {. acidophilus (strain } \\
\text { DDS1) (3 eight oz. cups of milk containing } 2 \times 106 \\
\text { CFU/ml per day) }\end{array}$ & 12 healthy subjects & $\begin{array}{l}\text { A decrease in } \beta \text {-glucuronidase and } \beta \text {-glucosidase } \\
\text { activity [60]. }\end{array}$ \\
\hline $\begin{array}{c}\text { Dietary supplementation with VSL\#3 probiotics } \\
\text { and inulin prebiotics }\end{array}$ & 7 chronic pigtail macaques & $\begin{array}{l}\text { Combination of pre and probiotics supported } \\
\text { increased immune function as well as enhanced } \\
\text { reconstitution CD4+ T cells by decreasing } \\
\text { inflammation and related fibrosis [61]. }\end{array}$ \\
\hline L. acidophilus (given as a fermented product) & 14 colon cancer patients & $\begin{array}{c}\text { A } 14 \% \text { decrease in mean } \beta \text {-glucuronidase } \\
\text { activity after two weeks [62]. }\end{array}$ \\
\hline
\end{tabular}




\begin{tabular}{|c|c|c|}
\hline $\begin{array}{c}\text { Enteral nutrition with Fresubin original fibre as } \\
\text { well as supplementation with VSL\#3 probiotics }\end{array}$ & 40 patients admitted in ICU & $\begin{array}{c}\text { Significantly reduced levels of TG, HDL and CRP } \\
\text { [63]. }\end{array}$ \\
\hline Lactobacillus rhamnosus GG + Bacilles lactis & 20 healthy humans & $\begin{array}{c}\text { Significant prevention of IL-2 secretion in } \\
\text { polypectomized and colon cancer patients [64]. }\end{array}$ \\
\hline High dose of VSL\#3 probiotics sachets & 30 rats with induced ulcers & $\begin{array}{c}\text { Significantly effective in augmenting gastric } \\
\text { ulcer healing [65]. }\end{array}$ \\
\hline
\end{tabular}

\section{Evidences of Clinical Trials And Adverse Effects Associated With Robotics'}

Due to outweighed health benefits of robiotics and their rapidly increasing market value, novel probiotic based products are constantly being reported [46-50]. The unique concept of microorganism assisted treatment of various diseases especially related to colon like colorectal cancer, inflammatory bowel syndrome, colitis and various types of diarrhoea is quite popular [51-55]. Extensive experiments suggest a range of potentially beneficial medicinal uses for robiotics. Among various approaches used for various diseases [56-60]. Microorganism assisted approach appears to be promising and hence some examples of evidences supporting the positive effects of robiotics are shown in the (Table 4). Though robiotics are supposed to exert myriad health benefits yet the exact mechanisms by which these microorganisms exhibit their effects are not yet known [61-64]. Hence their rapidly increasing use has apprehended various issues about safety arise from their desirable characteristics. Major areas of concern are as follows:

a. Translocation of robotic bacteria (i.e. crossing the gastrointestinal barrier and resulting in invasive infection) [3]. b. Possibility of transfer of antibiotic resistance from probiotic species to potentially pathogenic bacteria $[65,66]$.

c. Possible deleterious metabolic activity,

d. Immunologic effects of robotics which may include excessive immune stimulation [67].

e. Adverse effects especially in immune compromised, geriatric or pediatric patients [67].

\section{Translocation Associated Risk of Invasive Infection}

The diverse parameters affecting the ability of translocation include injury to mucosal layer, immune deficiency, prematurity of gut, abnormalities in intestinal microorganism (e.g. overgrowth) $[68,69]$. And adherence of the bacteria to the mucosal surface [70]. Various risks associated with translocation of robotic [7175]. Bacteria are shown in (Table 5). Furthermore, 9 cases of bowel ischemia have been observed in the robotic treated patients, 8 of whom died [75-79]. As per some surveys, it has been reviewed that bacteraemia or fungemia attributed to robotic consumption has given rise to large number of case reports in comparison to naturally occurring infections [80].

Table 5: Translocation associated risks of robotic bacteria.

\begin{tabular}{|c|c|c|}
\hline Probiotic involved & Reported facts & References \\
\hline $\begin{array}{l}\text { L. rhamnosus, } \\
\text { L. acidophilus, } \\
\text { B. lactic }\end{array}$ & $\begin{array}{c}\text { Translocation and cause invasive infection in an } \\
\text { oral mouse model. }\end{array}$ & [71] \\
\hline L. rhamnosus strain GG and L. refuter) & $\begin{array}{l}\text { More adherences to mucus than whole tissue, } \\
\text { Significantly greater adherence to intestinal } \\
\text { mucus. }\end{array}$ & {$[72]$} \\
\hline L. rhamnosus & $\begin{array}{l}\text { Translocation involves phosphatidylinositol- } \\
\text { specific phospholipase C. }\end{array}$ & [73] \\
\hline L. rhamnosus strain GG L. casei and L. refuter & $\begin{array}{l}\text { Amongst } 15 \text { probiotics and } 44 \text { faecal samples, } \\
\text { increased translocation in the clinical isolates vs. } \\
\text { probiotic strains could have been facilitated by } \\
\text { their increased ability to adhere to mucus. }\end{array}$ & [74] \\
\hline Multispecies probiotic preparation & $\begin{array}{l}\text { Higher mortality rate i.e. }(16 \%) \text { was observed } \\
\text { in patients with predicted acute pancreatitis } \\
\text { treated with a multispecies probiotic } \\
\text { preparation and } 6 \% \text { mortality in the placebo } \\
\text { treated group. }\end{array}$ & [75] \\
\hline $\begin{array}{l}\text { L. rhamnosus, } \\
\text { B. subtilis }\end{array}$ & Several cases of bacteraemia were reported. & {$[76,77]$} \\
\hline S. boulardii & Several cases of fungemia were reported. & [78] \\
\hline
\end{tabular}

\section{Transfer of Antibiotic Resistance}

Indiscriminate use of antibiotics in human and veterinary medicine has posed a major threat of antibiotic resistance and has become a common characteristic in microorganisms. This has ultimately has led to a problematic concern to cure microbial infection [81]. In this context, some studies support the positive value of antibiotic resistance in robotic species. It also has been reported that robotic bacteria are resistant against various 
antibiotics like vancomycin, tetracycline, ampicillin etc. The pool of such resistant genes may help the robotic to grow in the vicinity of antibiotic course and hence supposed to be beneficial for the host. On the other hand, antibiotic resistance may be either natural i.e. intrinsic or acquired. In the case of robotic bacteria, lactobacilli exhibit a vast variety of naturally occurring resistances however these are supposed to be non-transmissible type and hence there is no safety concern. These are safe as these carry peptidoglycan precursors terminating with D-lactate instead of target precursor for vancomycin activity terminating with D-alanine [82].

Most of these types of strains carrying intrinsic vancomycin resistance include L. rhamnosus and L. casei, have a long history of safe use [83]. Though, there is no evidence that vancomycin resistant lactobacilli could transfer the resistance to other bacteria, hence these robotic strains are not involved in transmission of genes despite their capacity to do so. It is evident from different studies that resistance genes are either located on mobile genetic elements (such as plasmids or transposes) or at the bacterial chromosome. Transfer through mobile elements amongst bacteria is easy as compared to chromosomal transfer, specifically for lactobacilli. It has been reviewed that tetracycline (tet $(\mathrm{M})$, tet $(\mathrm{W})$, tet( $(0)$ and tet $(\mathrm{O} / \mathrm{W})$, erythromycin and clindamycin [erm (B)] and streptomycin [aph (E) and sat (3)] genes are already present in several lactic acid bacteria and Bifidobacterium [84].

Above all most of the determinants were located on the bacterial chromosome, except for tet(M), which was identified on plasmids in Lactococcus lactis. Although lactobacilli strains are alleged to be naturally resistant to vancomycin which appears to be chromosomally located and non transferable to other genera yet they do occur [85-87]. As a result of transfer of vancomycin resistance (VanA cluster) from enterococcus to a commercial strain of Lactobacillus acidophilus. The same has been established both in vitro and in the gut of mice [88]. Hence their safety implications should be taken into consideration.

\section{Risk of Gastrointestinal and Immunologic Toxicity}

Multiple theoretical concerns also have been raised regarding deleterious metabolic activities of robiotics. Initially it has been emphasized that robotics produce gastrointestinal toxicity as a result of their enzymatic activity as particular focus is on lactic acid production. Human metabolism is assumed to produce L (+)-isomer of lactic acid whereas bacterial metabolism of carbohydrates produce D (-) lactate directly or indirectly from L (+)-lactate. It may happen due to the presence of enzyme $\mathrm{D} / \mathrm{L}$-lactate racemase which is possessed by various lactobacilli species [89].

But human metabolic pathway is unable to metabolize and excrete D (-)-lactate and as a result acidosis occurs. Another major concern is increased risk for colon cancer (due to an action on mucus producing cells along with stimulated proliferation by bile salt deconjugate activity) [90]. Although no evidences are supporting such issues. In addition mucus degradation (as bacterial endocarditic has been reported in patients receiving robotics) and platelet aggregating activity has also been reported. Aggregation properties of 10 Lactobacillus strains in patients with infective endocarditic had also been observed particularly with L. rhamnosus and L. paracasei [91].

\section{Regulatory Concerns Associated with Robotics}

The robotic industry is in an emerging phase due to increased demand of robotic based products. Robotics is supposed to play the safest role as therapeutic agents for even cancer, AIDS and other affected individuals. Their use as chemotherapeutic agents is being explored due to endless list of their benefits and virtually these are treatment remedies without any side effects. Despite having beneficial effects, status of the robotics as a component of food is not clear in health industry. They are used as preventive or curative therapy and hence most of robotic bacteria are sold overthe-counter as dietary supplements or in food products such as yogurt, as well as in the pharmaceutical preparations too. Currently robotic based industries are flooding the market with a range of commercial robotic products and these are targeting healthy as well as diseased persons due to their specific nutritional, functional or therapeutic characteristics.

But this rapidly emerging robotic industry is facing a major threat due to lack of globally acknowledged consistent guiding principles and as a matter of fact plethora of products calling themselves robotics, but not clinically proven are entering to the market. Presently due to the absence of harmonized universally accepted definition and categorization robotics are on the boundary of being food, dietary supplement or medicine. In the absence of comprehensive regulatory rules, it is important to screen the use of these novel strains into our own robotic based foods as well as robotic based pharmaceuticals for their safe and judicious use. Presently irrational selection of robotics, design and usage of robotic products has led to stringent challenges for the scientific community in concern to their safety factors. So the use of these novel strains into our own food needs a cautious assessment for their effectiveness and safety prior to their use for therapeutic purposes.

All the leading countries across the globe are now considering the significance of robotics and regulatory views are continuously altering, still there are certain considerable confusions and challenges due to diverse categorization. Regulatory bodies, food scientists, manufacturers and even consumers are not clear about the claims associated with robotics, which need to be addressed for the successful marketing and safe usage of functional foods. In the absence of any regulatory principle or even with weak principles there would always be a possibility of marketing of ineffective products with false claims. Robotic industry being in its initial stages is required to ensure safe, swift and successful usage of these microorganisms. Although European group has made significant contributions in harmonizing the regulatory framework, yet due to conflict of interest in various countries with respect to harmonization of regulatory guidelines, there is urgent need for 
proper regulatory framework and harmonization of regulation and guidelines on robotics at global level to ensure the quality and safety for active utilization of functional foods in different countries.

As long as regulations improve and research continues to separate facts from fiction, robotic based products are likely to play an increasingly important role in health maintenance and disease prevention in coming years. Till date, only pharmaceutical products are considered under the category of drugs whereas robotics is included under dietary supplements, natural health products, food supplements or functional foods. Hence the status of these products is full of ambiguities because various regulatory agencies in different countries are defining and categorizing them differently. At the same time regulatory authorities categorize them as per their intended use and hence no single definition is there for these products. Due to this inappropriate division, it is difficult to enforce appropriate use of this product [92].

\section{Conclusion}

Robotics has gained significant commercial momentum and consumer acceptance in recent years due to increased awareness about health and prolonged history of safe use. Currently robotic based products are available in market as food claiming nutritional values and pharmaceuticals having therapeutic benefits. Robotics therapy has already made its way to cure a number of diseases, alleviate lactose intolerance, and reduce serum cholesterol levels, cancer, constipation and hypercholesterolemia. Human clinical trials are performed in an attempt to establish the efficacy of products in the prevention or treatment of human disease. Regulatory control of robotics by various agencies across the globe under different categories and diverse laws has raised serious concerns. Consideration of robotics under functional foods, dietary supplements, natural health products, food supplements in different countries have created an illusion for global acceptance of these products.

Furthermore application of robotics as pharmaceuticals and their diverse spectrum of therapeutic effectiveness in treatment of various ailments (as co-therapy) has also contributed in its rapid success and market acceptance. However no consideration of these products under pharmaceuticals till date has some serious questions to be answered through regulatory laws in favour of public health and safety. Further future clinical trials, involving large numbers of patients, will be mandatory to achieve definite evidence of the preventive and curative role of robotics in medical practice. Details about correct formulations in terms of amount of bacteria, viability and associated growth factors, will be required in order to standardize the administration schedule and achieve homogeneous, comparable results on selected cohorts of recruited patients.

The information compiled in the manuscript clearly demonstrates lack of standardization as a major challenge for robotic industry. There is a need of assessment of efficacy and safety of these novel strains prior to inclusion in our functional foods. It can also be concluded that harmonization of regulatory guidelines/ standards may lead to rise in market value of robotic products, high robotic consumption, decreased entry of misbranded and counterfeit products and hence lead to safe and judicious use of robotics.

\section{References}

1. Munthali DC, Logan JWM, Wood TG, Nyirenda GKC (1999) Termite distribution and damage to crops on small holder farms in southern Malawi. International Journal of Tropical Insect Science 19(1): 43-49.

2. Glaciela K, Julio CP, Jaime AA, Deise CS (2006) Termite Activity in Relation to Natural Grassland Soil Attributes. Scientia Agricola 63(6): 583-588.

3. Grohmann C, Oldeland J, J Stoyan D, Linsenmair KE (2010) Multi-scale pattern analysis of a mound-building termite species. Insect Sociaux 57(4): 477-486.

4. Logan JW, Cowie RH, Wood TG (1990) Termite (Isoptera) control in agriculture and forestry by non-chemical methods: a review. Bulletin of entomological research 80(3): 309-330.

5. Pearce MJ (1997) Termites: Biology and Pest Management. CAB International, New York, USA, pp. 172.

6. Yanyong C Ouab S, Nit K (2003) Belt-Transect: A sampling Device for Termite Communities Study. Kasetsart J 37: 150-156.

7. Jones SC (1990) Effects of population-density on tunnelling by Formosan subterranean termite (Isoptera, Rhinotermitidae) through treated soil. Journal of Economic Entomology 83(3): 875-878.

8. Zeidler J Hanrahan S, Scholes M (2002) Termite species richness, composition and diversity on five farms in southern Kunene region, Namibia. African Zoology 37(1): 7-11.

9. Krishna K (1969) In Krishna K, Weesner FM (Eds.) Biology of termites, I Academic Press, London and New York, USA, pp. 598.

10. Edwards R, Mill AE (1986) Termites in Buildings. Their biology and control. The Rentokil Library, Rentokil Ltd, East Grinstead, UK pp. 261.

11. Akhtar MS (1972) Studies on the Taxonomy and zoogeography of the termites of Pakistan. Thesis, University of the Punjab, Lahore, Pakistan.

12. Akhtar MS (1975) Taxonomy and zoogeography of the termites (Isoptera) of Bangladesh. Bull Dept Zool University Punjab (NS): 1-199.

13. Chhotani OB, Das BC (1979) Variability and morphometric analysis of the soldier caste in Heterotermes indicola (Wasmann). Proc Symp Zool Surv India 1: 47-52.

14. Akhtar MS (1981) Some observations on swarming and development of incipient colonies of termites of Pakistan. Pakistan J Zool 10: 283-290.

15. Akhtar MS (1991) Feeding responses to wood and wood extracts by Bifiditermes beesoni (Gardner) (Isoptera: Kalotermitidae) Int Biodet Bull 17: 21-25.

16. Rajagopal D (2002) Economically important termite species in India. Sociobiology 41: 33-46.

17. Remadevi OK, Nagaveni HC, Muthukrishnan R, Vijayalakshmi G (2005) Natural resistance of wood of Cleistanthus collinus (Roxb.) Benth and Hook against wood decay fungi and termites. Journal of the Indian Academy of Wood Science 2: 45-50.

18. Lee CC, Neoh KB, Lee CY (2014) Colony Size Affects the Efficacy of Bait Containing Chlorfluazuron Against the Fungus-Growing Termite Macrotermes gilvus (Blattodea: Termitidae). Journal of economic entomology 107(6): 2154-2162.

19. Grace JK, Tome CHM, Shelton TG, Oshiro RJ, Yates JR (1996) Baiting studies and considerations with Coptotermes formosanus (Isoptera: Rhinotermitidae) control in Hawaii. Sociobiology 28(3): 511-520. 
20. Grace JK, Tome CHM, Shelton TG, Oshiro RJ, Yates III JR (1996) Baiting studies and considerations with Coptotermes formosanus (Isoptera: Rhinotermitidae) control in Hawaii. Sociobiology 28(3): 511-520.

21. De Souza O, Miramontes O, Santos CA, Bernardo DL (2000) Social facilitation affecting tolerance to poisoning in termites (Insecta, Isoptera). Insectes soc 48(1): 21-24.

22. Khan RM, Singh AP (1985) Control of termites in wheat crop with insecticides applied through irrigation. Entomon 10: 197-201.

23. Anonymous (2000) Finding Alternatives to Persistent Organic Pollutants (PoPs) for Termite Management. Global IPM Facility Expert Group on Termite Biology and Management. Stockholm Convention. Food and Agriculture Organization, Rome 118-168.

24. Kumawat KC (2001) Evaluation of some insecticides against field termites Odontotermes obesus and Microtermes obesi in wheat, Triticum aestivum. Pakistan Journal of Entomology 9: 51-53.

25. Rana J Ombir S, Dahiya KK (2001) Management of termite, Microtermes obesi (Holmgren) in wheat, Triticulum aestivum through seed treatment. Annales de biologie Clinique 17: 207-209.

26. Saran RK, Rust MK (2007) The toxicity, uptake, and transfer efficiency of fipronil in western subterranean termites (Isoptera: Rhinotermitidae). Journal of economic entomology 100(2): 495-508.

27. Remmen LN, Su NY (2005) Tunneling and mortality of eastern and Formosan subterranean termites (Isoptera: Rhinotermitidae) in sand treated with thiamethoxam or fipronil. Journal of economic entomology 98(3): 906-910.

28. Thorne BL, Breisch NL (2001) Effects of sublethal exposure to imidacloprid on subsequent behavior of subterranean termite Reticulitermes virginicus (Isoptera: Rhinotermitidae). Journal of economic entomology 94(2): 492-498.

29. Horwood MA (2007) Rapid degradation of termiticides under field conditions. Australian journal of Entomology 46(1): 75-78.

30. Cai W, Henderson G (2013) Evidence of Formosan Subterranean Termite Group Size and Associated Bacteria in the Suppression of Entomopathogenic Bacteria, Bacillus thuringiensis subspecies israelensis and thuringiensis. Annals of the Entomological Society of America 106(4): 454-462.

31. (2008) IRAC, IRAC mode of action classification.

32. Hosie AM, Baylis HA, Buckingham SD, Sattelle DB (1995) Actions of the insecticide fipronil on dieldrin-sensitive and -resistant GABA receptors of Drosophila melanogaster. British Journal of Pharmacology 116: 909912.

33. Tingle CC, Rother JA, Dewhurst CF, Lauer S, King WJ (2003) Fipronil: environmental fate, ecotoxicology, and human health concerns. Reviews of Environmental Contamination and Toxicology 176: 1-66.
34. Kard B (2001) Gulfport studies stay the course. Pest Control 69: 30-33.

35. Henderson G (2003) Liquid learning. Pest Control 31: 48-50.

36. Ibrahim SA, Henderson G, Fei H (2003) Toxicity, repellency, and horizontal transmission of fipronil in the Formosan subterranean termite (Isoptera: Rhinotermitidae). Journal of Economic Entomology 96(2): 461-467.

37. Shelton TG, Grace JK (2003) Effects of exposure duration on transfer of nonrepellent termiticides among workers of Coptotermes formosanus Shiraki (Isoptera: Rhinotermitidae). Journal of Economic Entomology 96(2): 456-460.

38. Osbrink WLA, Lax AR, Brenner RJ (2001) Insectide suceptibility in Coptotermes formosanus and Reticulitermes virginicus(Isoptera: Rhinotermitidae). Journal of economic entomology 94(5): 1217-1228.

39. Song D, Hu XP (2006) Effects of dose, donor-recipient interaction time and ratio on fipronil transmission among the Formosan subterranean termite nestmates (Isoptera: Rhinotermitidae). Sociobiology 48(2): 237-246.

40. Ching Chen Lee, Kok Boon Neoh, Chow Yang Lee (2014) Colony Size Affects the Efficacy of Bait Containing Chlorfluazuron Against the Fungus-Growing Termite Macrotermes gilvus (Blattodea: Termitidae). Journal of economic entomology 107(6): 2154-2162.

41. Kaschuk G, Santos JCP, Almeida JA, Sinhorati DC, Berton Junior JF (2006) Termite activity in relation to natural grassland soil attributes. Scientia Agricola 63(6): 583-588.

42. Verma M, Sharma S, Prasad R (2009) Biological alternatives for termite control: a review. International Biodeterioration and Biodegradation 63(8): 959-972.

43. Richard JF, Baddi GA, Costa C, Guiresse M, Kaemmerer M, et al. (2006) Comparative study on humic acids of the mound of a wood-feeding termite and of the litter directly below in the Amazon river delta. Journal of Chemistry Ecological 22: 201-209.

44. Su NY (2005) Response of the Formosan subterranean termites (Isoptera: Rhinotermitidae) to baits or non repellent termiticides in extended foraging arenas. Journal of economic entomology 98(6): 21432152.

45. Sarcinelli TS, Schaefer CEG, de Souza Lynch L, Arato HD, Viana JHM, et al. (2009) Chemical, physical and micromorphological properties of termite mounds and adjacent soils along a toposequence in Zona da Mata, Minas Gerais State, Brazil. Catena 76(2): 107-113.

46. Thorne BL, Russek Cohen E, Forschler BT, Breisch NL, Traniello JF (1996) Evaluation of mark-release-recapture methods for estimating forager population size of subterranean termite (Isoptera: Rhinotermitidae) colonies. Environmental Entomology 25(5): 938-951.

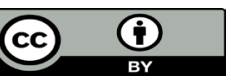

This work is licensed under Creative Commons Attribution 4.0 License

Submission Link: https://biomedres.us/submit-manuscript.php

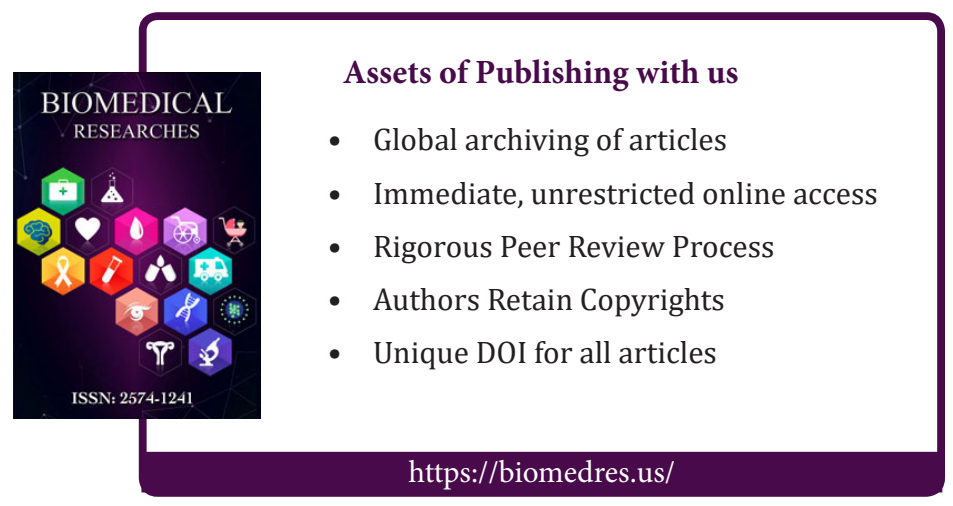

